\title{
Application of karyotype analysis combined with BACs-on-Beads for prenatal diagnosis
}

\author{
YUAN FANG $^{1 *}$, GUANGMING WANG $^{2^{*}}$, LIZE GU $^{1}$, JINGJING WANG $^{1}$, \\ FENG SUO ${ }^{1}$, MAOSHENG GU $^{1}$ and LINGSHAN GOU ${ }^{1}$ \\ ${ }^{1}$ Center for Genetic Medicine, Xuzhou Maternity and Child Health Care Hospital; \\ ${ }^{2}$ Department of Radiology, Xuzhou Central Hospital, Xuzhou, Jiangsu 221009, P.R. China
}

Received December 25, 2017; Accepted July 25, 2018

DOI: $10.3892 / \mathrm{etm} .2018 .6574$

\begin{abstract}
This study explored the clinical application of karyotype analysis combined with BACs-on-Beads (BoBs) technology in prenatal diagnosis. A total of 558 pregnant women who were admitted to Xuzhou Maternity and Child Health Care Hospital from July 2015 to June 2017 were enrolled in this study. All the subjects underwent amniocentesis. BoBs assay was performed for subjects in the observation group, and karyotype analysis was performed for subjects in the control group. The main technical indicators of subjects in the two groups were summarized, and cases of chromosome abnormalities were further evaluated. Clinical follow-up of their pregnancy and neonatal birth was undertaken. Finally, the chromosomal manifestations of these patients were compared with those of normal male and normal female, as well as common chromosomal abnormalities. All 558 pregnant women underwent amniocentesis again. Karyotype analysis combined with BoBs assay of amniotic fluid was performed. Cases of chromosomal abnormalities detected were: 75 cases of trisomy 21, 20 cases of trisomy 18, 1 case of trisomy 13, 27 cases of sex chromosomal abnormalities, 12 cases of balanced chromosome translocation, and 2 cases of chromosome microdeletion. The results indicated that karyotype analysis combined with BoBs technology for prenatal diagnosis was easy to perform, and provided quick results with high accuracy. The two testing methods were complementary to each other, which significantly improved the diagnostic rate of chromosomal abnormalities thus reducing birth defects and guiding continued pregnancy of high-risk pregnant women.
\end{abstract}

Correspondence to: Dr Maosheng Gu and Dr Lingshan Gou, Center for Genetic Medicine, Xuzhou Maternity and Child Health Care Hospital, 46 Heping Road, Yunlong, Xuzhou, Jiangsu 221009, P.R. China

E-mail: qeu2pu@163.com

E-mail: shaolin007007@163.com

*Contributed equally

Key words: BACs-on-Beads technology, karyotype analysis, prenatal diagnosis

\section{Introduction}

Down syndrome (DS), also known as trisomy 21 syndrome, is the most common human chromosomal condition (1). Its incidence in newborns ranges from $1 / 800$ to $1 / 1000$ (2). The incidences of trisomy 18 and trisomy 13 syndromes were next only to that of trisomy 21 syndrome (3). The major characteristics of clinical manifestations are severe congenital mental retardation and unique facial features, which are often accompanied by a variety of congenital malformations or other abnormalities (4). These syndromes cannot be cured. Prenatal diagnosis is the only way to prevent birth of children with defects (5). Therefore, early screening, early diagnosis, and timely termination of pregnancy are important measures to reduce birth defects (6).

Traditional prenatal diagnosis is actually conventional karyotype analysis of fetal chromosomes, which detects limited types of chromosomal abnormalities, and takes longer to obtain results (7). Prenatal BACs-on-Beads (BoBs) is a newly-developed and efficient molecular diagnostic technique. This new technology can quickly detect 5 common aneuploidy abnormalities (21, 18, 13, X, Y), and 9 common microdeletion syndromes as well (8).

In order to improve the prenatal diagnostic rate and reduce the incidence of birth defects, in this study, prenatal BoBs assay was performed together with the traditional karyotype analysis, aiming to explore potential benefits of combination of the two testing methods in prenatal diagnosis.

\section{Subjects and methods}

Subjects. A total of 558 pregnant women who were admitted to Xuzhou Maternity and Child Health Care Hospital from July 2015 to June 2017 were enrolled in this study. All the subjects gave their informed consent for the study. At 19-24 weeks of pregnancy, the subjects underwent amniocentesis for karyotype analysis combined with BoBs assay of amniotic fluid. Prenatal conditions of pregnant women included: Advanced maternal age, high-risk with prenatal screening, abnormal findings with non-invasive prenatal testing (NIPT), fetal ultrasound abnormalities, chromosomal abnormalities in pregnant women or their husbands, and previous birth of child with chromosomal abnormalities. 


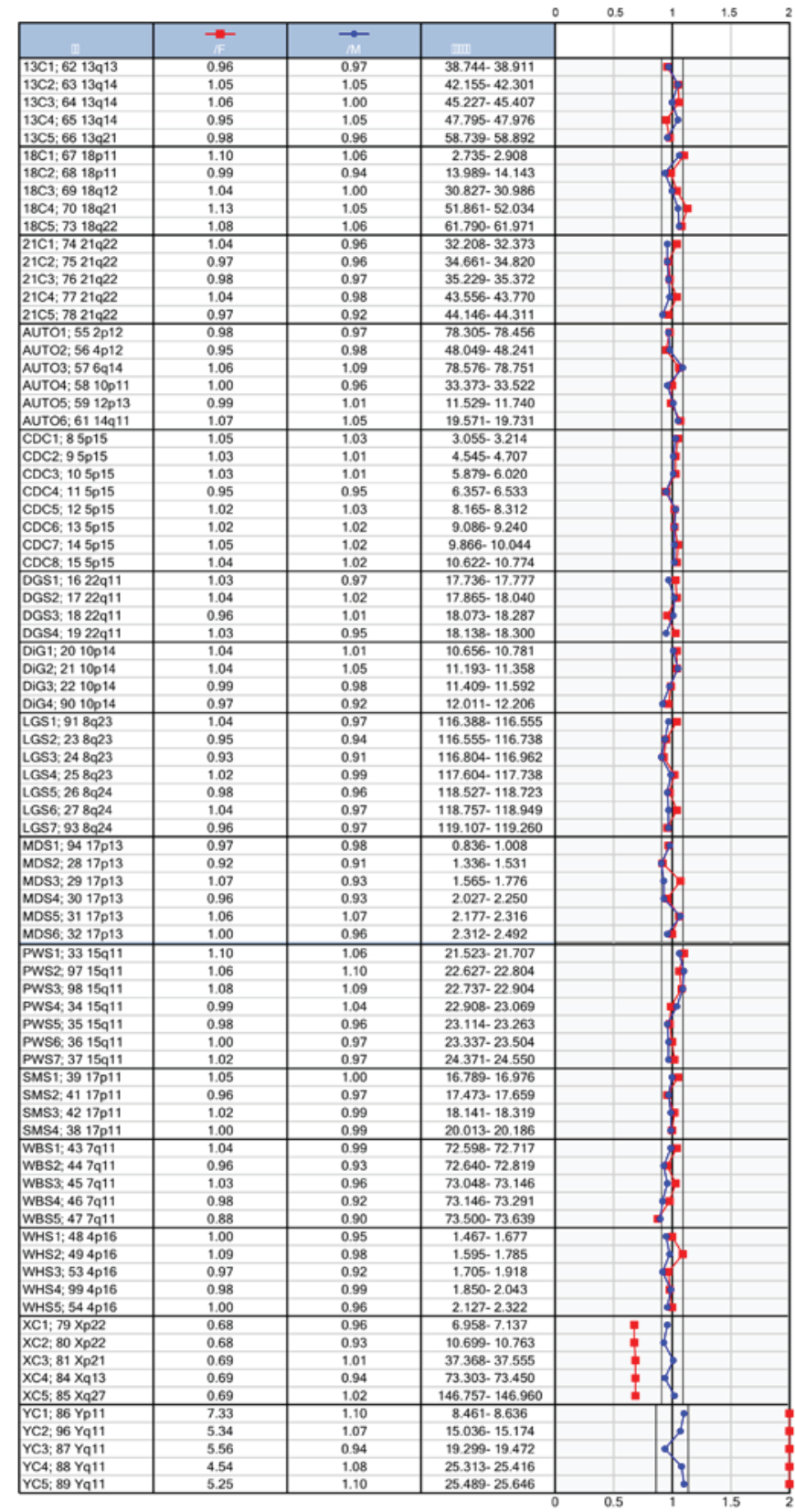

Figure 1. Technical report of prenatal BoBs assay for a normal male. Red dots, sample DNA/female reference DNA; blue dots, sample DNA/male reference DNA. F, female; M, male; BoBs, BACs-on-Beads.

The study was approved by the Ethics Committee of Xuzhou Maternity and Child Health Care Hospital.

\section{Methods}

Amniocentesis. Subjects signed the informed consent form before undergoing the procedure. Amniocentesis was performed under ultrasound guidance. Amniotic fluid (25 ml) was withdrawn, of which $20 \mathrm{ml}$ was cultured to allow for karyotype analysis of chromosomes, and the remaining $5 \mathrm{ml}$ was used for BoBs assay.

Chromosome karyotype analysis. Approximately $20 \mathrm{ml}$ of amniotic fluid was centrifuged at $2,500 \mathrm{x}$ g for $10 \mathrm{~min}$ at $4^{\circ} \mathrm{C}$ to separate amniotic cells. The cells were cultured, harvested and
Table I. Karyotype analysis (control group) and BACs-onBeads assay (observation group).

\begin{tabular}{|c|c|c|}
\hline Groups & Test time & Items tested \\
\hline Observation & $24 \mathrm{~h}$ & $\begin{array}{c}21,18,13, \mathrm{X}, \mathrm{Y} \text { chromosomes } \\
\text { and } 9 \text { microdeletions }\end{array}$ \\
\hline Control & 3 weeks & 46 chromosomes \\
\hline
\end{tabular}

Table II. Prenatal conditions of high-risk pregnant women that underwent amniocentesis.

Prenatal conditions

Cases

Trisomy 21 with non-invasive prenatal testing

60

Trisomy 18 with non-invasive prenatal testing

Trisomy 13 with non-invasive prenatal testing

Sex chromosomal abnormalities with

non-invasive prenatal testing

High-risk with prenatal screening

(not including positive findings with

non-invasive prenatal testing)

Advanced maternal age

(not including positive findings with

non-invasive prenatal testing)

Abnormal findings with

color Doppler ultrasound

(not including positive findings with

non-invasive prenatal testing)

Chromosomal abnormalities in

pregnant women or their husbands

Previous birth of child with

chromosomal abnormalities

Total

mounted on glass slides after routine treatments for chromosome G-banded analysis. On each slide, 30 stained metaphases were examined, and 5 karyograms were created for chromosome analysis. If a suspicious chromosomal abnormality or chromosomal polymorphism was found, the count number of metaphases was then increased to 50, and the number of karyograms was increased to $\geq 20$ for a more reliable result.

BoBs assay. Genomic DNA was extracted from approximatley $5 \mathrm{ml}$ of amniotic fluid using DNA extraction reagents according to manufacturer's instructions. BoBs kit (Perkin Elmer, Waltham, MA, USA) was used for BoBs assay. The beads were analyzed using a Luminex 200 cytometric acquisition system (Austin, TX, USA) for data collection. Data were analyzed using BoBsoft 2.0 software.

Indicators observed. The subjects were divided into the observation and control groups. Karyotype analysis was performed on the control group, and BoBs assay was performed on the observation group. The major technical indicators were summarized, and cases of chromosomal abnormalities were further evaluated. 
Table III. Prenatal diagnostic outcomes of pregnant women with different prenatal conditions.

\begin{tabular}{|c|c|c|c|c|c|c|}
\hline \multirow[b]{2}{*}{ Prenatal conditions } & \multicolumn{6}{|c|}{ Diagnostic outcome } \\
\hline & Trisomy 21 & Trisomy 18 & Trisomy 13 & $\begin{array}{c}\text { Sex } \\
\text { chromosomal } \\
\text { abnormalities }\end{array}$ & $\begin{array}{l}\text { Balanced } \\
\text { chromosome } \\
\text { translocation }\end{array}$ & $\begin{array}{l}\text { Chromosome } \\
\text { microdeletion }\end{array}$ \\
\hline $\begin{array}{l}\text { Positive findings with non-invasive } \\
\text { prenatal testing (T21, T18 and T13) }\end{array}$ & 60 & 16 & 1 & 24 & 0 & 0 \\
\hline $\begin{array}{l}\text { High-risk with prenatal screening } \\
\text { (not including positive findings } \\
\text { with non-invasive prenatal testing) }\end{array}$ & 2 & 0 & 0 & 2 & 0 & 0 \\
\hline $\begin{array}{l}\text { Advanced maternal age } \\
\text { (not including positive findings } \\
\text { with non-invasive prenatal testing) }\end{array}$ & 3 & 0 & 0 & 1 & 0 & 0 \\
\hline $\begin{array}{l}\text { Abnormal findings with } \\
\text { color Doppler ultrasound } \\
\text { (not including positive findings } \\
\text { with non-invasive prenatal testing) }\end{array}$ & 9 & 4 & 0 & 0 & 1 & 1 \\
\hline $\begin{array}{l}\text { Chromosomal abnormalities in } \\
\text { pregnant women or their husbands }\end{array}$ & 1 & 0 & 0 & 0 & 11 & 0 \\
\hline $\begin{array}{l}\text { Previous birth of child with } \\
\text { chromosomal abnormalities }\end{array}$ & 0 & 0 & 0 & 0 & 0 & 0 \\
\hline Total cases & 75 & 20 & 1 & 27 & 12 & 1 \\
\hline
\end{tabular}

Table IV. Comparison of diagnostic outcomes between observation group and control group.

\begin{tabular}{lcccccc}
\hline Groups & Trisomy 21 & Trisomy 18 & Trisomy 13 & $\begin{array}{c}\text { Sex } \\
\text { chromosomal } \\
\text { abnormalities }\end{array}$ & $\begin{array}{c}\text { Balanced } \\
\text { chromosome } \\
\text { translocation }\end{array}$ & $\begin{array}{c}\text { Chromosome } \\
\text { microdeletion }\end{array}$ \\
\hline Observation & 75 & 20 & 1 & 27 & 0 & 1 \\
Control & 75 & 20 & 1 & 27 & 12 & 0 \\
\hline
\end{tabular}

Statistical analysis. Statistical analysis was performed using the SPSS 19.0 software (IBM SPSS, Armonk, NY, USA). Comparison between multiple groups was done using one-way ANOVA test followed by post hoc test (Least Significant Difference). $\mathrm{P}<0.05$ was considered to indicate a statistically significant difference.

\section{Results}

Comparsion of karyotype analysis (control group) and BoBs assay (observation group). Detection time was shorter in the observation group (BoBs technique) than in the control group, and the number of chromosomal loci detected was less than that of the control group. However, 9 more microdeletions were added to the detection range (Table I).

Number of amniocentesis performed for high-risk pregnant women with different prenatal conditions. Amniocentesis was mainly performed for pregnant women with high-risk with prenatal screening (non-invasive positive was not included), advanced maternal age pregnant women (non-invasive positive was not included) and pregnant women with sex chromosomal abnormalities with NIPT (Tables II and III).

Diagnostic outcomes of pregnant women in the observation group and the control group. Test results of chromosomal abnormalities showed that the diagnostic outcomes of two groups were similar in trisomy 21 , trisomy 18 , trisomy 13 and sex chromosomal abnormalities. Balanced chromosome translocation were detected in the control group but not in the observation group. Chromosome microdeletion were detected in the observation group but not in the control group. The two tests complement each other, and the difference was statistically significant $(\mathrm{p}<0.05)$ (Table IV).

Reports of normal findings with BoBs assay. DNA probes were added to the fluorescently-labeled (red) microspheres. After amplification by PCR and fluorescent labeling (blue), the genotypes of the samples were determined. Figs. 1 and 2 show the genomic sequence of normal males and females. 


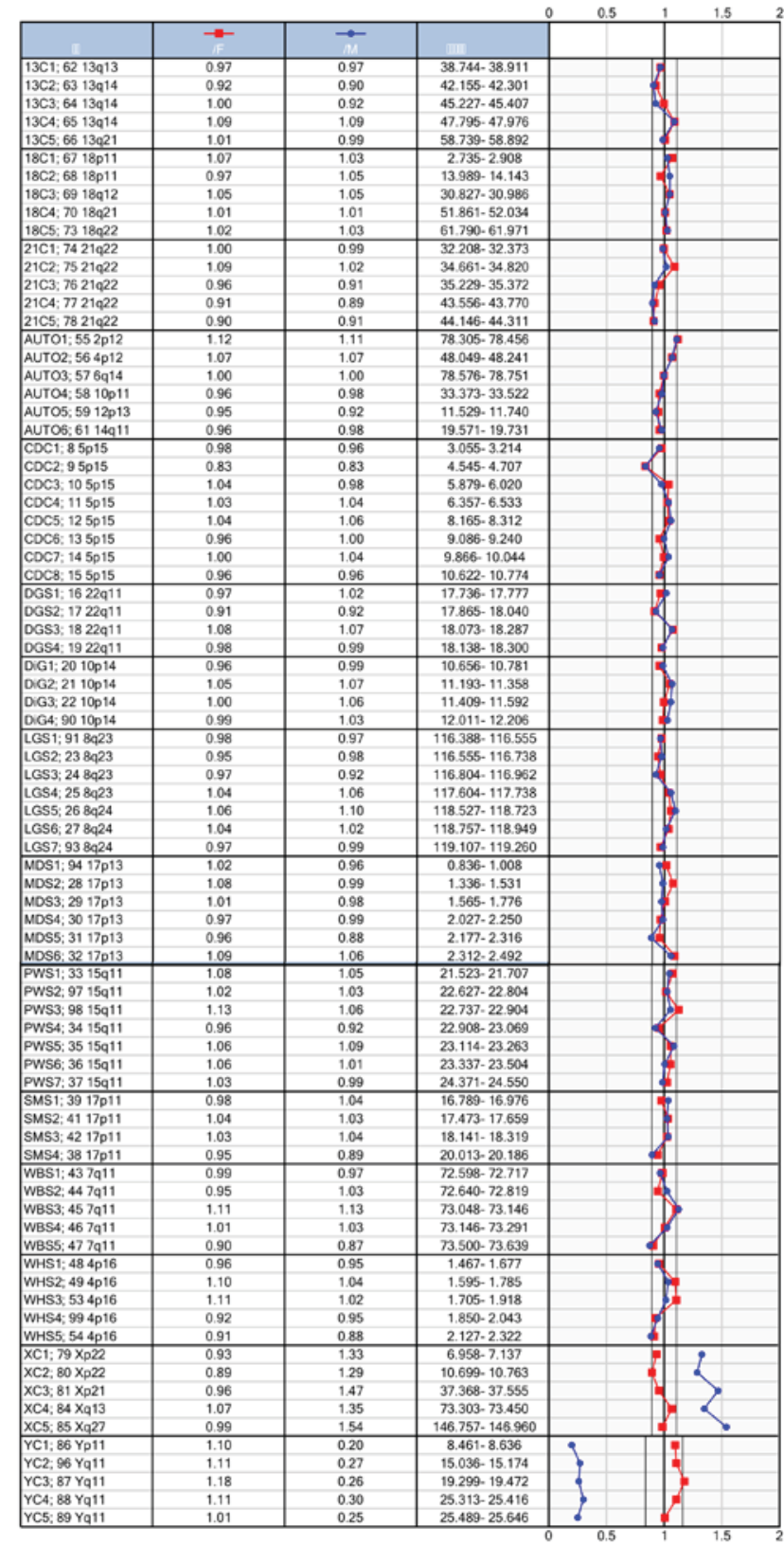

Figure 2. Technical report of prenatal BoBs assay for a normal female. Red dots, sample DNA/female reference DNA; blue dots, sample DNA/male reference DNA. F, female; M, male; BoBs, BACs-on-Beads.

Abnormal findings with BoBs assay. Targets selection is highly specific. Menu-based detection can quickly detect 21-trisomy aneuploidy, which can compensate the limitations of karyotype analysis. Fig. 3 shows the detection results of BoBs for prenatal 21-trisomy.

\section{Discussion}

China currently has a population of 1.4 billion, and is the first most populous country in the world. Not only is the birth rate the highest in the world, but the total number of birth defects also rank first in the world (9). Previous studies have confirmed that trisomy 21 is the most common type of neonatal birth defects, followed by trisomy 18 , trisomy 13 , and aneuploidy of sex chromosomes X and Y (10). The present strategy of

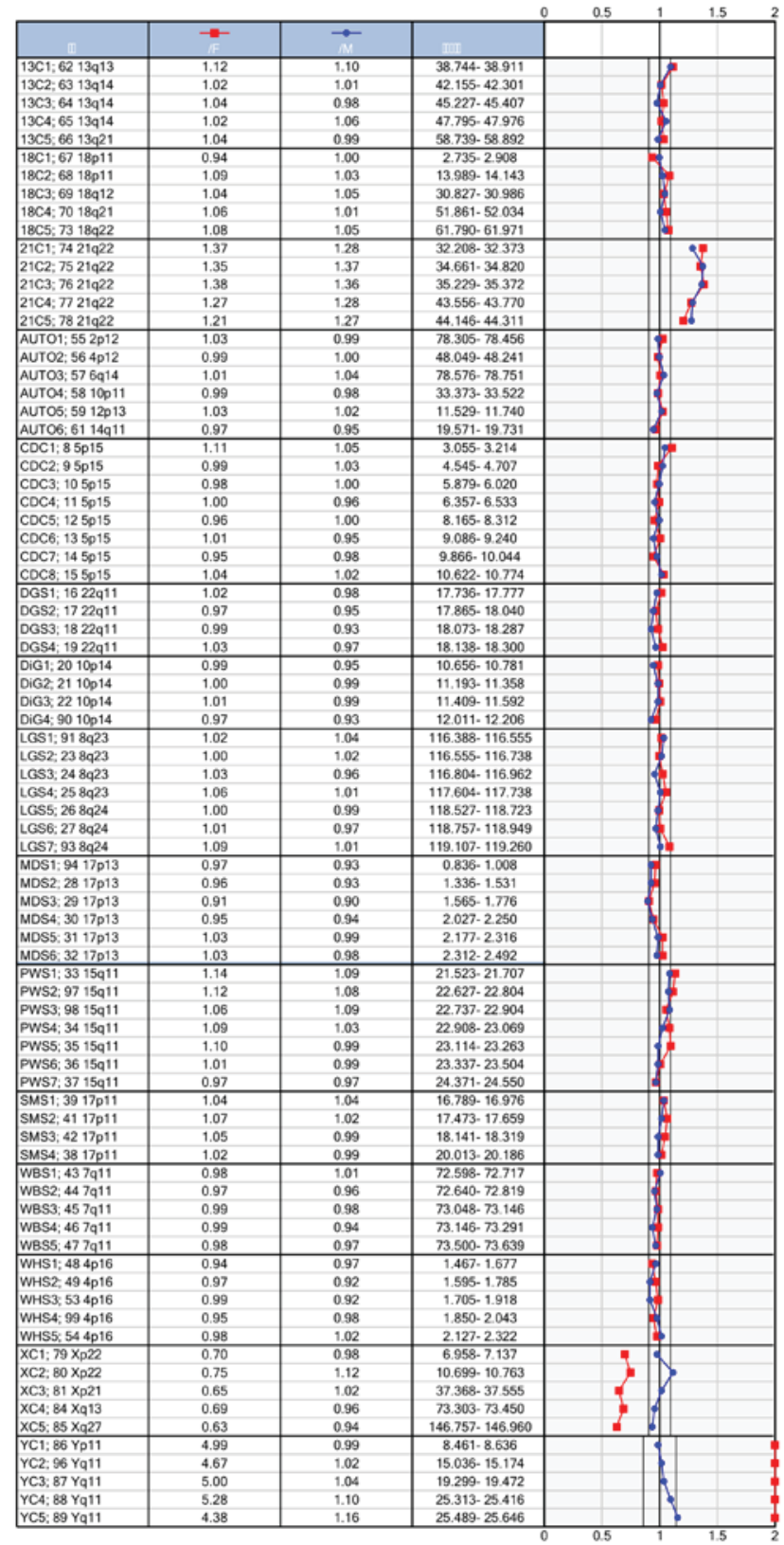

Figure 3. Technical report of prenatal BoBs assay for trisomy 21. Red dots, sample DNA/female reference DNA; blue dots, sample DNA/male reference DNA. Data in red are abnormal parameters. F, female; M, male; BoBs, BACson-Beads.

managing birth defects due to chromosomal abnormalities is implementation of secondary prevention, i.e., intervention through prenatal screening and diagnosis (11). Karyotype analysis following amniocentesis was the gold standard of prenatal diagnosis in previous studies (12), which was highly sensitive and specific, and had an almost $100 \%$ prenatal diagnostic rate for fetal chromosomal abnormalities. However, the technology requires a longer period of time to obtain results and has low resolution, thus only detection of larger mutations is allowed. Moreover, karyotype analysis requires high skill level to process the chromosome samples, and results were interpreted with high subjectivity and in the case of an unsuccessful amniotic fluid cell culture, the whole experiment is in vain $(13,14)$. 
Prenatal BoBs technology is a cytogenetic assay for rapid prenatal diagnosis. Results obtained from the chromosome analysis are characteristic for both normal male and normal female. In this assay, a small amount of DNA sample was required to perform analysis of multiple chromosomes and find abnormalities. Trisomy 21 served as an example of an abnormal result. In addition, BoBs assay takes less time to obtain results than traditional karyotype analysis. In a typical assay, the results can be obtained within $24 \mathrm{~h}$, which greatly reduces anxiety and relieves psychological stress in high-risk pregnant women. Except for fast results, this technology also enables high throughput by analysis of more than 92 samples at the same time (15). Through molecular karyotyping, genomic DNA in identified target region is amplified, and target deletion is detected (16). In addition to detecting aneuploidy of chromosomes 13, 18, 21, and sex chromosomes X and Y (17), BoBs technology enables aberration detection in 9 additional meticulously chosen microdeletion regions (18). Thereby diagnostic accuracy can be improved, and shortcomings in abnormal cell culture for karyotype analysis can be offset to some extent $(19,20)$.

In this study, in order to explore the clinical application of BoBs assay combined with karyotype analysis, results obtained by BoBs assay were compared with results obtained by traditional karyotype analysis of the same enrolled pregnant women. The two testing methods yielded exactly the same diagnostic outcomes in the detection of trisomy 21, trisomy 18 , trisomy 13 , and sex chromosomal abnormalities. Balanced chromosome translocation was detected only by karyotype analysis (control group), whereas chromosome microdeletion was detected only by BoBs assay (observation group). Thus, the two testing methods were complementary to each other.

In conclusion, karyotype analysis combined with BoBs technology for prenatal diagnosis was easy to perform, and provided quick results with high accuracy. Combined use of the two testing methods significantly improved the diagnostic rate of chromosomal abnormalities thus reducing birth defects and guiding continued pregnancy of high-risk pregnant women.

\section{Acknowledgements}

Not applicable.

\section{Funding}

This study was funded by The First Batch of Training Project for reserve medical youth in Xuzhou (no. 2014011).

\section{Availability of data and materials}

The datasets used and/or analyzed during the present study are available from the corresponding author on reasonable request.

\section{Authors' contributions}

YF and GW contributed significantly to writing the manuscript and conducted amniocentesis. LG helped with karyotype analysis of chromosomes. JW and FS performed BoBs assay. MG and LG interpreted statistical analysis. All authors read and approved the final study.

\section{Ethics approval and consent to participate}

The present study was approved by the Ethics Committee of Xuzhou Maternity and Child Health Care Hospital. Signed informed consents were obtained from the patients or the guardians.

\section{Patient consent for publication}

Not applicable.

\section{Competing interests}

The authors declare that they have no competing interests.

\section{References}

1. Bianca I, Geraci G, Gulizia MM, Egidy Assenza G, Barone C Campisi M, Alaimo A, Adorisio R, Comoglio F, Favilli S, et al: Consensus Document of the Italian Association of Hospital Cardiologists (ANMCO), Italian Society of Pediatric Cardiology (SICP), and Italian Society of Gynaecologists and Obstetrics (SIGO): Pregnancy and congenital heart diseases. Eur Heart J Suppl 19 (Suppl D): D256-292, 2017.

2. Pandya VK and Sutariya HC: Unilateral multicystic renal dysplasia: Prenatal diagnosis on ultrasound. Saudi J Kidney Dis Transpl 28: 916-920, 2017.

3. Choy KW, Kwok YK, Cheng YK, Wong KM, Wong HK, Leung KO, Suen KW, Adler K, Wang CC, Lau TK, et al: Diagnostic accuracy of the BACs-on-Beads ${ }^{\mathrm{TM}}$ assay versus karyotyping for prenatal detection of chromosomal abnormalities: A retrospective consecutive case series. BJOG 121: $1245-1252,2014$

4. Grati FR, Molina Gomes D, Ferreira JC, Dupont C, Alesi V, Gouas L, Horelli-Kuitunen N, Choy KW, García-Herrero S, de la Vega AG, et al: Prevalence of recurrent pathogenic microdeletions and microduplications in over 9500 pregnancies. Prenat Diagn 35: 801-809, 2015.

5. Marcato L, Turolla L, Pompilii E, Dupont C, Gruchy N, De Toffol S, Bracalente G, Bacrot S, Troilo E, Tabet AC, et al: Prenatal phenotype of Williams-Beuren syndrome and of the reciprocal duplication syndrome. Clin Case Rep 2: 25-32, 2014.

6. Rosenfeld JA, Morton SA, Hummel C, Sulpizio SG, McDaniel LD, Schultz RA, Torchia BS, Ravnan JB, Ellison JW and Fisher AJ: Experience using a rapid assay for aneuploidy and microdeletion/microduplication detection in over 2,900 prenatal specimens. Fetal Diagn Ther 36: 231-241, 2014

7. Mei J, Wang H and Zhan L: 10p15.3p13 duplication inherited from paternal balance translocation $(46, X Y, t(5 ; 10)(\mathrm{q} 35.1 ; \mathrm{p} 13))$ identified on non-invasive prenatal testing. J Obstet Gynaecol Res 43: 1076-1079, 2017.

8. García-Herrero S, Campos-Galindo I, Martínez-Conejero JA, Serra V, Olmo I, Lara C, Simón C and Rubio C: BACs-on-Beads technology: A reliable test for rapid detection of aneuploidies and microdeletions in prenatal diagnosis. BioMed Res Int 2014: 590298, 2014.

9. Choy RK, Chen Y, Sun XF, Kwok YK and Leung TY: BACson-beads: A new robust and rapid detection method for prenatal diagnosis. Expert Rev Mol Diagn 14: 273-280, 2014.

10. Piotrowski K, Halec W, Wegrzynowski J, Pietrzyk A, Henkelman M and Zajaczek S: Prenatal diagnosis of LangerGiedion Syndrome confirmed by BACs-on-Beads technique. Ginekol Pol 85: 66-69, 2014.

11. Ragni MV: Prenatal diagnosis by droplet digital PCR. Blood 130: 240-241, 2017.

12. Łaczmańska I and Stembalska A: New molecular methods in prenatal invasive diagnostics. Ginekol Pol 84: 871-876, 2013 (In Polish).

13. Baxter L and Adayapalam N: A comparative study of standard cytogenetic evaluation and molecular karyotyping for products of conception. Diagn Mol Pathol 22: 228-235, 2013.

14. Kiiski K, Roovere T, Zordania R, von Koskull H and HorelliKuitunen N: Prenatal diagnosis of 17p13.1p13.3 duplication. Case Rep Med 2012: 840538, 2012. 
15. Piotrowski K, Henkelman M and Zajaczek S: Will the new molecular karyotyping BACs-on-Beads technique replace the traditional cytogenetic prenatal diagnostics? Preliminary reports. Ginekol Pol 83: 284-290, 2012 (In Polish).

16. Vialard F, Simoni G, Gomes DM, Abourra A, De Toffol S, Bru F Martinez Romero MC, Nitsch L, Bouhanna P, Marcato L, et al: Prenatal BACs-on-Beads ${ }^{\mathrm{TM}}$ : The prospective experience of five prenatal diagnosis laboratories. Prenat Diagn 32: 329-335, 2012.

17. Popowski T, Vialard F, Leroy B, Bault JP and Molina-Gomes D Williams-Beuren syndrome: The prenatal phenotype. Am J Obstet Gynecol 205: e6-e8, 2011.

18. Shaffer LG, Coppinger J, Morton SA, Alliman S, Burleson J, Traylor R, Walker C, Byerly S, Lamb AN, Schultz R, et al: The development of a rapid assay for prenatal testing of common aneuploidies and microdeletion syndromes. Prenat Diagn 31: 778-787, 2011.
19. Fox KA and Lee W: Prenatal diagnosis and evaluation of abnormal placentation. Clin Obstet Gynecol 60: 596-607, 2017.

20. Llorens Salvador R, Viegas Sainz A, Montoya Filardi A, Montoliu Fornas G and Menor Serrano F: Evaluation of the fetal cerebellum by magnetic resonance imaging. Radiologia 59: 380-390, 2017 (In English, and Spanish).

This work is licensed under a Creative Commons Attribution-NonCommercial-NoDerivatives 4.0 International (CC BY-NC-ND 4.0) License. 